\title{
PENGARUH PENDEKATAN CONCRETE-PICTORIAL-ABSTRACT (CPA) TERHADAP PENCAPAIAN KEMAMPUAN SPATIAL SENSE (KSS) SISWA SD
}

Hafiziani Eka Putri ${ }^{1}$, Ratna Julianti ${ }^{2}$, Nahrowie Adjie ${ }^{3}$, Nur Endah Suryani ${ }^{4}$ e-mail:hafizianiekaputri@upi.edu,ratna.julianti@student.upi.edu

\begin{abstract}
ABSTRAK
Penelitian ini bertujuan untuk melihat pengaruh pembelajaran dengan pendekatan CPA terhadap pencapaian kemampuan spatial sense siswa Sekolah Dasar (SD) jika ditinjau secara keseluruhan dan Kemampuan Awal Matematis (KAM). Penelitian ini adalah penelitian kuasi eksperimen dengan desain kontrol pretes dan postes pada mata pelajaran Matematika dengan pokok bahasan bangun ruang terhadap 74 siswa sekolah dasar di Kecamatan Cikampek Kabupaten Karawang Jawa Barat. Penelitian ini dilakukan dengan dua kelompok belajar; kelompok yang menggunakan pendekatan CPA sebagai kelompok eksperimen, dan kelompok yang menggunakan pembelajaran konvensional sebagai kelompok kontrol. Analisis data baik secara deskriptif maupun inferensial menunjukkan bahwa pencapaian kemampuan spatial sense siswa yang mendapatkan pembelajaran dengan pendekatan CPA lebih baik dari siswa yang mendapatkan pembelajaran konvensional; baik ditinjau secara keseluruhan dan tiap kelompok KAM.Dengan demikian, pembelajaran CPA dapat mengembangkan kemampuan spatial sense siswa sekolah dasar.
\end{abstract}

Kata kunci: Pembelajaran dengan Pendekatan CPA, Kemampuan Spatial Sense dan Siswa Sekolah Dasar.

\footnotetext{
1,3 Dosen

2,4 Mahasiswa
} 


\section{A. PENDAHULUAN}

Matematika adalah ilmu yang sangat berperanpenting dalam kemajuan peradaban manusia dewasa ini. Matematika juga memiliki banyak peran dalam kemajuan IPTEK melalui berbagai cabang ilmu yang dimiliki, salah satunya yaitu geometri. Oleh karena itu, matematika sangat penting untuk diperkenalkan dengan baik dariusia dini karena manfaatnya akan terus terasa seiring perkembangan zaman. Geometri memiliki kaitan yangsangat erat dengan bangun ruang dan benda-benda dalam keseharian. Geometri dan berbagai konsep di dalamnya menduduki posisi khusus di dalam kurikulum matematika. Geometri memiliki kaitan yang erat sekali dengan Kemampuan Spatial Sense (KSS). Gardner (2004) menyebutkan bahwa KSS merupakan salah satudari 8 kecerdasan majemuk (multiple intelligences)yang dimiliki manusia antara lain Linguistik, matematislogis, spasial, kinestetis-jasmani, musikal, intrapersonal, interpersonal, dan naturalis.

National Council of Teachers
of Mathematics
(NCTM,
2000)menetapkan 5 standar isi dalam matematika, yang salah satunya yaitu geometri. Selain itu, terdapat unsur penggunaan visualisasi, penalaran spatial dan pemodelan. di dalam geometri. Hal ini menandakan bahwa KSS merupakan tuntutan kurikulum yang sangat perlu dikembangkan dengan sebaik-baiknya dalam pembelajaran. Dalam kurikulum nasional, dimulai tingkat SD hingga perguruan tinggi dituntut untuk menguasai materi geometri ruang dan geometri bidang yang berkaitan erat dengan kemampuan spatial sense. Hal ini sejalan dengan hal yang telah dikemukakan oleh NationalAcademy of Science (2006) bahwa kemampuan dan penginderaan spasial sense siswa harus dikembangkan dengan baik hal ini diharuskan karena KSS sangat berguna dalam memahamisifat-sifat dan relasi dalam geometri yang dapat dignakan untuk memecahkan masalah matematika serta masalahdalam keseharian. Oleh karena itu, dapat disimpulkan bahwa KSSmerupakan kemampuan yang penting untuk dimiliki siswa.

Kenyataan mengenai pentingnya KSS berbanding terbalik dengan kemampuan siswa yang kurang dalam pemahaman materi geometri. Hal ini sejalan dengan analisisTrends in International Mathematics and Science Study (TIMSS) tahun 2015, dengan sasaran populasi siswa kelas 4 $\mathrm{SD} / \mathrm{MI}$, Indonesia berada pada peringkat ke-45 dari 50 negara peserta. Salah satu pokok bahasan yang sulit bagi siswa Indonesia adalah Geometri. Dari hal tersebut, terlihat jelas bahwa siswa Indonesia masih sangat kurang dalam kemammpuan menyelesaikan soalsoal geometri.

$\begin{array}{lrr} & \text { Kurangnya } & \text { kemampuan } \\ \text { siswa } & \text { Indonesia } & \text { dalam }\end{array}$ menyelesaikan soal geometri dapat disebabkan karena kurangan KSS siswa SD di Indonesia. Kurangnya KSS ini sejalan dengan penelitian yang telah dilakukan oleh Saptini (2016) yang menyatakan bahwa kemampuan siswa SD dalam mengerjakan permasalahan geometri masih rendah. $\mathrm{Hal}$ ini didasarkan atas studi pendahuluan yang telah dilakukan Saptini di salah satu sekolah dasar mengenai volume bangun ruang. Rendahnya KSS siswa membuat peneliti tertarik untuk melakukan kajian lebih jauh tentang pengaruh penerapan pendekatan CPA terhadap pencapaian KSS Siswa di SD.

\section{B. KAJIAN TEORI}

Dalam pembelajaran matematika, hambatan yang sering 
terjadi di dalam kelasyaitu kurangnya alat peraga yang dignakann guru dalam pebelajaran matematika sehingga siswa sulit untuk memahami konsep pembelajaran yang abstrak. Sejalan dengan hal tersebut, Hasil survey Programme for International Student Assessment (PISA) 2000/2001 (dalam Suwaji, 2008) menunjukkan bahwa siswa lemah dalam geometri, khususnya dalam ;pemahaman ruang dan bentuk. Setelah dilakukan wawancara terhadap siswa, diketahui penyebab siswa tidak menyukai matematika karena pembelajarannnya tidak menarik dan kurang bergairah. Hal ini dikarenakan pembelajaran yang konvensional sehingga lebih berpusat pada guru (Teacher centered) juga minimnya alat peraga yang digunakann dalam pembelajaran matematika di kelas.

Dari permasalahan siswa yang dijelaskan di atas terdapat satu pendekatan yang dirasa cocok untuk meningkatkan kemampuan spatial sense siswa SD yaitu pendekatan Concrete-Pictorial-Abstract (CPA) atau Concrete-RepresentasiAbstract (CRA). Pendekatan CPA dipilih karena memiliki tahapan yang sesuai dengan tahap perkembangan kognitif siswa SD. Pendekatan CPA adalah pendekatan instruksional tiga langkah yang sangat efektif dalam mengajarkan konsep matematika. Langkah pertama disebut tahap konkret. Hal ini dikenal sebagai tahap "melakukan" dengan melibatkan objek berupa benda nyata (fisik) yang dimanipulasi untuk memecahkan masalah matematika. Pictorial (semi-konkret) adalah langkah berikutnya. Hal ini dikenal sebagai tahap "melihat" dengan melibatkan penggunaan gambar untuk mewakili objek dalam memecahkan masalah matematika. Langkah terakhir dalam pendekatan ini disebut tahap abstrak. Hal ini dikenal sebagai tahap "simbolis" yang hanya melibatkan penggunaan angka dan simbol dalam memecahkan masalah matematika. Sejalan dengan hal tersebut Witzel (2005) mengemukakan bahwa CPA merupakan pendekatan tiga fase yang berawal dari penggunaan benda konkret yang dimanipulasi, setelah tahap tersebut dilanjutkan dengan gambar yang dimanipulasi yang mana benda tersebut masih memiliki keterkaitan dengan benda konkrit pada fas esebelumnya, fase terakhir yaitu pembelajaran dengan menggunakan notasi abstrak seperti simbol dan angka. Mengajar siswa melalui tiga tahap belajar ini telah terbukti bermanfaat bagi siswa yang memiliki kesulitan dalam pembelajaran matematika. Melalui penjelasan di atas, dapat disimpulkan bahwa CPA merupakan pendekatan yang memiliki tahapantahapan yang cocok untuk meningkatkan kemampuan spatial sense. Hal ini sejalan dengan hasil penelitian yang telah dilakukan oleh Putri (2017)bahwa pendekatan CPA dapat menguntungkan semua siswa, karena telah terbukti sangat efektif dengan siswa yang memiliki kesulitan matematika. Mereka telah mengalami matematika dalam berbagai bentuk dari objek nyata, bergambar dan akhirnya ke simbol.

Pendekatan CRA sangat bermanfaat bagi siswa sekolah menengah yang memiliki kesulitan dengan pelajaran matematika. Salah satunya adalah penelitian yang dilakukan oleh Witzel, Mercer, dan Miller (2003) berupa penggunaan pendekatan CRA untuk mengembangkan keterampilan dasar matematika siswa dengan kesulitanbelajar. Siswa diajarkan untuk memecahkan persamaan aljabar baik menggunakan pendekatan CRA atau pendekatan tradisional. Penelitian ini melibatkan 37 siswa dari masing-masing kelas. Hasil penelitian tersebut menunjukan bahwa kedua kelompok 
menunjukkan peningkatan setelah diberikan perlakuan selama empat minggu, kelompok yang menerima pendekatan CRA secara signifikan mengungguli kelompok yang menerima pendekatan tradisional.

Kemampuan spatial sense merupakan kemampuan yang sangat penting untuk dikembangkan siswa. Hal ini sudah ditekankan oleh National Council of Teachers of Mathematics (NCTM) di Amerika Serikat yang telah memasukkan KSSsebagai salah satu kompetensi penting untuk ditingkatkan serta dikembangkan dalam pelajaran geometri, termaktub dalam Precollege Mathematicss Educational Standards (NCTM, 2000). Gardner (Harmony dan Theis, 2012) mengemukakan bahwa kemampuan spasial adalah kemampuan keruangan yang dapat dikatakansebagai kemampuan untuk memvisualisasikan gambar dan kemampuan mengenalbenda serta bentuk dengan tepat,seseorang yang memiliki KSS dapat melihat dan mengenali perubahan suatu benda dalam pikirannya sertadapat menggambarkan suatu hal atau benda bentuk nyata dalam pikiran berdasarkan apa yang dilihatnya, memiliki kepekaan terhadap keseimbangan, garis, relasi, warna, ruang dan bentuk,serta dapat mengungkapkan data dalam suatu grafik.

Indikator spatial senseyang digunaakan dalam penelitiann ini anatara lain: 1) mengidentifikasi dan mengklasifikasikan gambar geometri; 2) menginterpretasikan dan menggambarkan benda-benda tiga dimensi; dan 3) menerapkan pemahaman tentang keliling, luas, volume, dan ukuran sudut.

\section{METODE PENELITIAN}

Sampel. Sampel dalam penelitian ini adalah 74 siswa; terdiri dari 37 siswa dari kelompok eksperimen dan 37 siswa dari kelompok kontrol. Para siswa dalam kelompok eksperimen menerima pembelajaran menggunakan pendekatan CPA, sedangkan siswa pada kelompok kontrol menerima pembelajaran dengan pendekatan konvensional.

Penelitian ini merupakan penelitianquasi eksperiment (penelitian semu) dengan desain kontrol pretest dan posttest pada mata pelajaran Matematika dengan pokok bahasan bangun ruang terhadap 74 siswa sekolah dasar di kecamatan Cikampek Kabupaten Karawang Jawa Barat.

Pengumpulan data. Ada dua jenis data dalam penelitian ini, kuantitatif dan data kualitatif. Data kuantitatif diperoleh dari skor tes Kemampuan Awal Matematis (KAM), skor tes KSSyang didapat dari hasil posttestKSS. Data kualitatif diperoleh dokumentasi proses pembelajaran dengan menerapkan pendekatan CPA. Skor pencapaian KSS dikategorikan berdasarkan kelompok KAM (tinggi, sedang, dan rendah). Kelompok KAM pada kedua kelompok (eksperimen dan kontrol) diukur berdasarkanhasil tes KAM yang dilakukan pada awal pertemuan sebelum diberikannya perlakuan.

Analisis data. Analisis data dalam penelitian ini dilakukan dengan dua cara antara lain; analisis deskriptif dan analisis inferensial. Analisis deskriptif, menurut Sugiyono (2012), berfungsi untuk menjelaskan atau memberikan gambaran tentang subjek yang diteliti melalui data yang dikumpulkan dari sampel atau populasi. Analisis deskriptif pencapaianKSSsiswa didasarkan pada rata-rata dari skor posttest. Pencapaian KSS siswa ditentukan dalam tiga kriteria pencapaian yaitu rendah, sedang, dan tinggi. Penentuan ketiga kriteria ini disusun dengan menggunakan aturan pengelompokan yang dikemukakan 
oleh Arikunto (2012) yang tersaji dalam Tabel 1.

Tabel 1. Kriteria Pencapaian Kemampuan Spatial Sense

\begin{tabular}{|c|c|}
\hline Interval Pencapaian & $\begin{array}{c}\text { Kriteria } \\
\text { Pencapaian }\end{array}$ \\
\hline$x \geq \bar{x}+s d \cdot(0,7)$ & Tinggi \\
\hline $\begin{array}{l}\bar{x}-s d \cdot(0,7) \leq x \\
<\bar{x}+s d .(0,7)\end{array}$ & Sedang \\
\hline$x<\bar{x}+s d \cdot(0,7)$ & Rendah \\
\hline
\end{tabular}

(dimodifikasi dari Arikunto, 2012)

Keterangan:

$x \quad$ :Skor yang diperoleh tiap siswa

$\bar{x}$ : Rata-rata skor siswa secara keseluruhan

Sd: Standar deviasi (simpangan baku)

Analisis inferensial data dalam penelitian ini dilakukan melalui uji statistik. Jika data terdistribusi berdistribusi normal dan homogen, uji statistik hipotesis akan dilakukan dengan menggunakan uji parametrik (t-test). Jika data berdistribusi normal, tetapi tidak homogen, t-test juga akan dilakukan; Namun, jika data tidak berdistribusi normal, pengukuran statistik akan dilakukan menggunakan uji nonparametrik (uji Mann-Whitney).

\section{HASIL DAN PEMBAHASAN}

Pencapaian KSS siswa dilihat dari rata-rata skor posttest.

\section{Hasil Penelitian}

Rekapitulasi

hasil perhitungan untuk menentukan kriteria pencapaian KSS dapat dilihat pada Tabel 2.

Tabel 2. Kriteria Pencapaian KSS Siswa

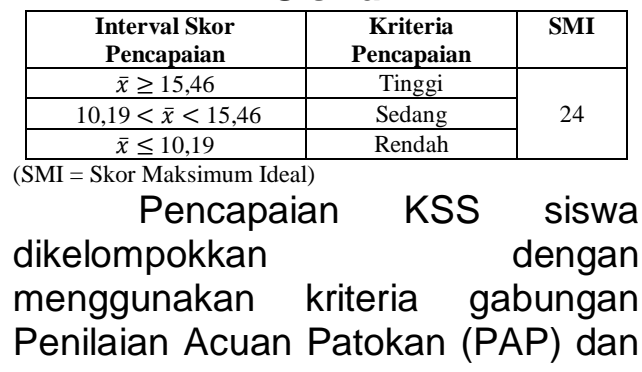

Penilaian Acuan Normatif (PAN) (Suherman dan Kusumah, 1990).

Rekapitulasi hasil analisis skor posttest KSS siswa berdasarkan pembelajaran secara keseluruhan disajikan pada Tabel 3.

Tabel 3. Rekapitulasi Skor Posttest KSS Siswa berdasarkan Pembelajaran

\begin{tabular}{|c|c|c|c|c|c|}
\hline \multirow{2}{*}{$\begin{array}{c}\text { Post } \\
\text { KSS }\end{array}$} & $\begin{array}{c}\text { Pembela } \\
\text { jaran }\end{array}$ & $\begin{array}{c}\text { Ter } \\
\text { kecil }\end{array}$ & $\begin{array}{c}\text { Ter } \\
\text { besar }\end{array}$ & $(\overline{\boldsymbol{x}})$ & \multirow{2}{*}{$\boldsymbol{S} \boldsymbol{d}$} \\
\hline \multirow{2}{*}{$\begin{array}{c}\text { SMI } \\
24\end{array}$} & CPA & 12 & 24 & 15,97 & 2,30 \\
\cline { 2 - 5 } & $\begin{array}{c}\text { Konvens } \\
\text { ional }\end{array}$ & 7 & 18 & 11,32 & 2,94 \\
\hline
\end{tabular}
memperlihatkan bahwa pencapaian KSS siswa yang mendapatkan pembelajaran dengan pendekatan CPA lebih tinggi dari siswa yang mendapatkan pembelajaran konvensional. Pencapaian KSS siswa yang mendapatkan pembelajaran dengan pendekatan CPA berada pada kriteria tinggi, sedangkan pencapaian KSS siswa yang mendapatkan pembelajaran konvensional berada pada kriteria sedang.

Rekapitulasi hasil analisis skor posttest KSS berdasarkan pembelajaran ditinjau dari kelompok KAM dapat dilihat pada Tabel 4.

Tabel 4. Rekapitulasi Skor Posttest KSS Siswa berdasarkan Pembelajaran ditinjau dari Kelompok KAM

\begin{tabular}{|c|c|c|c|c|c|}
\hline \multicolumn{6}{|c|}{ Posttest KSS (SMI=24) } \\
\hline \multirow{2}{*}{$\begin{array}{c}\text { Kelompok } \\
\text { KAM }\end{array}$} & \multirow{2}{*}{$\begin{array}{c}\text { Pembel } \\
\text { ajaran }\end{array}$} & \multicolumn{2}{|c|}{ Skor } & \multirow[b]{2}{*}{$\bar{x}$} & \multirow[b]{2}{*}{$S d$} \\
\hline & & $\begin{array}{c}\text { Ter } \\
\text { kecil }\end{array}$ & $\begin{array}{c}\text { Ter } \\
\text { besar }\end{array}$ & & \\
\hline \multirow[b]{2}{*}{ Tinggi } & CPA & 16 & 24 & 19,33 & 4,16 \\
\hline & $\begin{array}{c}\text { Konven } \\
\text { sional }\end{array}$ & 10 & 18 & 14,40 & 2,88 \\
\hline \multirow[b]{2}{*}{ Sedang } & $\mathrm{CPA}$ & 13 & 20 & 16,05 & 1,99 \\
\hline & $\begin{array}{c}\text { Konven } \\
\text { sional }\end{array}$ & 7 & 14 & 11,09 & 2,12 \\
\hline \multirow[b]{2}{*}{ Rendah } & $\mathrm{CPA}$ & 12 & 18 & 15,08 & 1,66 \\
\hline & $\begin{array}{c}\text { Konven } \\
\text { sional }\end{array}$ & 7 & 13 & 9,56 & 1,79 \\
\hline
\end{tabular}

Berdasarkan Tabel 4 dapat dilihat bahwa pencapaian KSS siswa untuk setiap kelompok KAM yang mendapatkan pembelajaran dengan pendekatan CPA lebih tinggi dari 
siswa yang mendapat pembelajaran konvensional. Pada kelompok KAM tinggi dan sedang, pencapaian KSS siswa untuk kelompok KAM tinggi yang mendapatkan pembelajaran dengan pendekatan CPA berada pada kriteria tinggi, sedangkan untuk kelompok KAM tinggi yang mendapatkan pembelajaran konvensional berada pada kriteria sedang. Pada kelompok KAM rendah, pencapaian KSS siswa untuk kelompok KAM rendah yang mendapatkan pembelajaran CPA berada pada kriteria sedang. Sedangkan, kelompok KAM rendah yang mendapatkan pembelajran konvensional berada pada kriteria rendah. Tabel 4 juga memperlihatkan bahwa pada kedua kelompok pembelajaran (CPA dan konvensional) pencapaian KSS siswa kelompok KAM tinggi lebih tinggi dari kelompok KAM sedang dan KAM rendah. Begitupun pencapaian KSS siswa pada kelompok KAM sedang lebih tinggi dari kelompok KAM rendah. Dengan demikian, pembelajaran dengan pendekatan CPA dapat lebih mengembangkan KSS siswa pada setiap kelompok KAM dibandingkan dengan pembelajaran konvensional. Berikut ini disajikan gambar untuk lebih memperjelas perbedaan pencapaian KSS siswa berdasarkan kelompok pembelajaran ditinjau dari kelompok KAM.

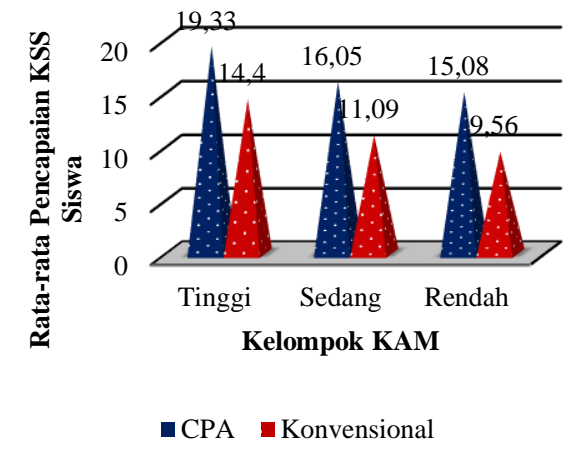

Gambar 1. Pencapaian KSS Siswa berdasarkan Pembelajaran ditinjau dari Kelompok KAM
Untuk mendukung hasil analisis deskriptif, analisis inferensial dilakukan dengan menggunakan uji statistik. Hipotesis yang digunakan dalam uji inferensial perbedaan siswa dalam pecapaianKSS adalah sebagai berikut:

$\mathrm{H}_{0}: \mu_{1}=\mu_{2}$ Tidak erdapat perbedaan pencapaianKemampua n Spatial Sense (KSS) siswa yang mendapat pembelajaran dengan penerapan pendekatan CPA dan siswayang mendapat

pembelajaran

konvensional ditinjau secara keseluruhan.

$\mathrm{H}_{1}: \mu_{1}>\mu_{2} \quad$ Pencapaian

Kemampuan Spatial Sense(KSS) siswa yang mendapat pembelajaran dengan penerapan pendekatan CPA lebih tinggi dari siswayang mendapat pembelajaran konvensional ditinjau secara keseluruhan.

Kriteria pengujian: Jika $p$ value (sig. 1-arah) lebih besar dari 0,05 maka $\mathrm{H}_{0}$ diterima, dan dalam hal lainnya $\mathrm{H}_{0}$ ditolak.

Rekapitulasi hasil uji perbedaan rata-rata pencapaian KSS siswa berdasarkan pembelajaran ditinjau secara keseluruhan disajikan pada Tabel 5.

\begin{tabular}{|c|c|c|c|c|}
\hline $\begin{array}{c}\text { Pembelaja } \\
\text { ran }\end{array}$ & $\begin{array}{c}\mathrm{U} \\
\text { Mann- } \\
\text { Whitney }\end{array}$ & $\mathbf{Z}$ & $\begin{array}{c}p \text {-value } \\
\text { (sig) }\end{array}$ & Ket. \\
\hline CPA & \multirow{2}{*}{159,500} & \multirow{2}{*}{$-5,707$} & \multirow{2}{*}{0,000} & \multirow{2}{*}{$\begin{array}{c}\text { Ada } \\
\text { Perbedaar }\end{array}$} \\
\hline $\begin{array}{c}\text { Konvensio } \\
\text { nal }\end{array}$ & & & & \\
\hline
\end{tabular}

Berdasarkan hasil perhitungan pada Tabel 5, dapat dilihat bahwa untuk rata-rata 
pencapaian KSS p-value(sig.1-arah) lebih kecil dari 0,05 maka $\mathrm{H}_{0}$ ditolak. Artinya jika ditinjau secara keseluruhan, pencapaian KSS siswa yang mendapatkan pembelajaran dengan pendekatan CPA lebih baik secara signifikan daripada siswa yang mendapatkan pembelajaran konvensional.

Rekapitulasi hasil uji normalitas data pencapaian dan KSS siswa ditinjau dari kelompok KAM dapat dilihat pada Tabel 6.

Tabel 6. Uji Normalitas Data Pencapaian KSS Siswa ditinjau dari Kelompok KAM

\begin{tabular}{|c|c|c|c|c|}
\hline \multirow{2}{*}{$\begin{array}{c}\text { Kelompok } \\
\text { KAM }\end{array}$} & Pembelajaran & Statistik & $d f$ & $\begin{array}{c}\text { p-value } \\
\text { (sig.2- } \\
\text { arah })\end{array}$ \\
\cline { 3 - 5 } & & 0,923 & 3 & 0,463 \\
\hline \multirow{2}{*}{ Tinggi } & CPA & Shapiro-Wilk & & \\
\cline { 2 - 5 } & Konvensional & 0,861 & 10 & 0,078 \\
\hline \multirow{2}{*}{ Sedang } & CPA & 0,929 & 21 & 0,130 \\
\cline { 2 - 5 } & Konvensional & 0,953 & 11 & 0,683 \\
\hline \multirow{2}{*}{ Rendah } & CPA & 0,967 & 13 & 0,860 \\
\cline { 2 - 5 } & Konvensional & 0,918 & 16 & 0,157 \\
\hline
\end{tabular}

Berdasarkan Tabel 6 nampak bahwa data pencapaian KSS pada kedua pembelajaran di setiap kelompok KAM memiliki $p$-value (sig.2-arah) lebih besar dari 0,05 sehingga $\mathrm{H}_{0}$ diterima, artinya data berdistibusi normal. Untuk itu perlu dilakukan uji homogenitas varians untuk data pencapaian dan KSS pada kedua pembelajaran untuk tiap kelompok KAM.

Uji homogenitas varians pencapaian dan KSS dilakukan dengan uji Levene. Rekapitulasi hasil uji homogenitas varians pencapaian dan KSS siswa ditinjau dari kelompok KAM dapat dilihat pada Tabel 7 .

Tabel 7. Rekapitulasi Hasil Uji Homogenitas Varians Pencapaian KSS Siswa ditinjau dari Kelompok KAM

\begin{tabular}{|c|c|c|c|c|}
\hline $\begin{array}{c}\text { Kelompok } \\
\text { KAM }\end{array}$ & Pembelajaran & $n$ & $F_{\text {hitung }}$ & $\begin{array}{c}\text {-value } \\
\text { (sig.2- } \\
\text { arah) }\end{array}$ \\
\hline \multirow{2}{*}{ Tinggi } & CPA & 3 & \multirow{2}{*}{0,537} & \multirow{2}{*}{0,479} \\
\hline & Konvensional & 10 & & \\
\hline \multirow{2}{*}{ Sedang } & $\mathrm{CPA}$ & 21 & \multirow{2}{*}{0,061} & \multirow{2}{*}{0,852} \\
\hline & Konvensional & 11 & & \\
\hline \multirow{2}{*}{ Rendah } & CPA & 13 & \multirow{2}{*}{0,331} & \multirow{2}{*}{0,586} \\
\hline & Konvensional & 16 & & \\
\hline
\end{tabular}

Tabel 7 di atas menunjukkan bahwa untuk setiap kelompok KAM tinggi, sedang dan rendah untuk data pencapaian KSS siswa seluruhnya memiliki nilai $p$-value (sig.2-arah) lebih besar dari 0,05 maka $\mathrm{H}_{0}$ diterima.Oleh karena itu, dapat disimpulkan bahwa varians kedua populasi homogen. Selanjutnya, akan dilakukan uji perbedaan rata-rata dengan uji- $t$ untuk keseluruhan kelompok KAM tersebut.

Hipotesis yang digunakan untuk uji perbedaan rata-rata pencapaian dan KSS siswa ditinjau dari kelompok KAM (tinggi, sedang dan rendah) dijabarkan sebagai berikut.

Hipotesis uji perbedaan rata-rata pencapaian KSS untuk kelompok KAM tinggi:

$\mathrm{H}_{0}: \mu_{1 T}=\mu_{2 T}$ Tidak ada perbedaan pencapaian

Kemampuan Spatial Sense (KSS) siswa yang mendapat pembelajaran dengan pendekatan CPA dan siswa yang mendapat pembelajaran konvensional ditinjau dari kelompok KAM tinggi.

$\mathrm{H}_{1}: \mu_{1 T}>\mu_{2 T}$ Pencapaian

Kemampuan Spatial Sense (KSS) siswa yang mendapat pembelajaran dengan pendekatan CPA lebih baik dari siswa yang mendapat

pembelajaran konvensional ditinjau dari kelompok KAM tinggi.

Hipotesis uji perbedaan rata-rata pencapaian KSS kelompok KAM sedang:

$\mathrm{H}_{0}: \mu_{1 S}=\mu_{2 S}$ Tidak ada perbedaan pencapaian

Kemampuan Spatial Sense (KSS) siswa 


$$
\begin{aligned}
& \text { yang mendapat } \\
& \text { pembelajaran dengan } \\
& \text { pendekatan CPA dan } \\
& \text { siswa yang mendapat } \\
& \text { pembelajaran } \\
& \text { konvensional ditinjau } \\
& \text { dari kelompok KAM } \\
& \text { sedang. } \\
& \mathrm{H}_{1}: \mu_{1 S}>\mu_{2 S} \text { Pencapaian } \\
& \text { Kemampuan Spatial } \\
& \text { Sense (KSS) siswa } \\
& \text { yang mendapat } \\
& \text { pembelajaran dengan } \\
& \text { pendekatan CPA lebih } \\
& \text { baik dari siswa yang } \\
& \text { mendapat } \\
& \text { pembelajaran } \\
& \text { konvensional ditinjau } \\
& \text { dari kelompok KAM } \\
& \text { sedang. }
\end{aligned}
$$

\begin{tabular}{|c|c|c|c|c|c|c|c|}
\hline $\begin{array}{c}\text { Kelom } \\
\text { pok } \\
\text { KAM } \\
\end{array}$ & $\begin{array}{c}\text { Pembel } \\
\text { ajaran }\end{array}$ & $\begin{array}{c}\text { Rata- } \\
\text { rata }\end{array}$ & $t_{\text {hitung }}$ & $d f$ & $t_{\text {tabel }}$ & $\begin{array}{l}\text {-value } \\
\text { (sig.1- } \\
\text { arah) } \\
\end{array}$ & Ket \\
\hline \multirow[b]{2}{*}{ Tinggi } & CPA & 19,333 & \multirow{2}{*}{2,380} & \multirow[b]{2}{*}{11} & \multirow{2}{*}{2,201} & \multirow{2}{*}{0,0185} & \multirow{2}{*}{$\begin{array}{c}\mathrm{H}_{0} \\
\text { ditolak }\end{array}$} \\
\hline & $\begin{array}{c}\begin{array}{c}\text { Konven } \\
\text { sional }\end{array} \\
\end{array}$ & 14,400 & & & & & \\
\hline \multirow[b]{2}{*}{ Sedang } & $\mathrm{CPA}$ & 16,048 & \multirow[b]{2}{*}{6,554} & \multirow[b]{2}{*}{30} & \multirow[b]{2}{*}{2,042} & \multirow[b]{2}{*}{0,000} & \multirow{2}{*}{$\begin{array}{c}\mathrm{H}_{0} \\
\text { ditolak }\end{array}$} \\
\hline & $\begin{array}{c}\text { Konven } \\
\text { sional }\end{array}$ & 11,091 & & & & & \\
\hline \multirow{2}{*}{ Rendah } & $\mathrm{CPA}$ & 15,077 & \multirow{2}{*}{8,534} & \multirow{2}{*}{27} & \multirow{2}{*}{2,051} & \multirow{2}{*}{0,000} & \multirow{2}{*}{$\underset{\text { ditolak }}{\mathrm{H}_{0}}$} \\
\hline & $\begin{array}{c}\text { Konven } \\
\text { sional }\end{array}$ & 9,562 & & & & & \\
\hline
\end{tabular}

Hipotesis uji perbedaan rata-rata pencapaian KSS kelompok KAM rendah:

$$
\begin{aligned}
& \mathrm{H}_{0}: \mu_{1 R}=\mu_{2 R} \text { Tidak ada perbedaan } \\
& \text { pencapaian } \\
& \text { Kemampuan Spatial } \\
& \text { Sense (KSS) siswa } \\
& \text { yang mendapat } \\
& \text { pembelajaran dengan } \\
& \text { pendekatan CPA dan } \\
& \text { siswa yang mendapat } \\
& \text { pembelajaran } \\
& \text { konvensional ditinjau } \\
& \text { dari kelompok KAM } \\
& \text { rendah. } \\
& \mathrm{H}_{1}: \mu_{1 R}>\mu_{2 R} \text { Pencapaian } \\
& \text { Kemampuan Spatial } \\
& \text { Sense (KSS) siswa } \\
& \text { yang mendapat } \\
& \text { pembelajaran dengan } \\
& \text { pendekatan CPA lebih } \text { baik dari siswa yang } \\
& \text { mendapat } \\
& \text { pembelajaran } \\
& \text { konvensional ditinjau } \\
& \text { dari kelompok KAM } \\
& \text { rendah. }
\end{aligned}
$$

Kriteria pengujian: Jika $p$ value (sig.1-arah) lebih besar dari 0,05 maka $\mathrm{H}_{0}$ diterima, dan dalam hal lainnya $\mathrm{H}_{0}$ ditolak.

Rekapitulasi hasil uji perbedaan rata-rata pencapaian
KSS siswa berdasarkan pembelajaran ditinjau dari kelompok KAM (tinggi, sedang, dan rendah) dapat dilihat pada Tabel 8.

Tabel 8. Rekapitulasi Hasil Uji Perbedaan Rata-rata Pencapaian KSS Siswa ditinjau dari Kelompok KAM

Berdasarkan datapada Tabel 8, dapat dilihat semuap-value (sig.1arah) untuk pencapaian KSS pada tiap kelompok KAM lebih kecil dari 0,05, maka $\mathrm{H}_{0}$ ditolak. Oleh karena itu, dapat disimpulkan bahwa pencapaian KSS siswa yang mendapat pembelajaran dengan pendekatan CPA lebih baik secara signifikan dari siswa yang mendapat pembelajaran konvensional.

Dengan demikian, dapat disimpulkan bahwa pencapaian KSS siswa yang mendapat pembelajaran dengan pendekatan CPA lebih baik secara signifikan dari siswa yang mendapat pembelajaran konvensional, jika dilihat secara keseluruhan dan kelompok KAM (tinggi, sedang, rendah).

\section{Pembahasan}

Temuan menunjukkan bahwa pencapaian Kemampuan Spatial Sense (KSS)siswa yang mendapat pembelajaran dengan pendekatan CPA lebih tinggi secara signifikan dari siswa yang mendapat pembelajaran konvensional, jika dilihat secara keseluruhan dan kelompok KAM (tinggi, sedang, rendah).Hal ini sejalan dengan hasil penelitian Witzel (2005) yang menyimpulkan bahwa siswa yang belajar memecahkan transformasi 
persamaan

aljabar melalui

pendekatan CPA memperoleh hasil

lebih tinggi daripada siswa yang menerima pengajaran tradisional.

Selanjutnya, hasil penelitian

American Institutes for Research

(dalam Yuliawaty, 2011)

menyebutkan bahwa, siswa yang

belajar dengan menggunakan benda

konkret, representasi mentalnya

berkembang lebih tepat dan lebih

komprehensif; sering menunjukkan

motivasi lebih dan prilaku

mengerjakan tugas dengan baik; memahami ide-ide matematis, dan lebih baik dalam menerapkan ide-ide untuk situasi kehidupan.

Temuan ini merujuk pada tahapan pendekatan CPA yangs sesuai dengan tahap perkembangan kognitif siswa usia sekolah dasar. Polya (dalam Suwangsih dan Tiurlina, 2009) berpendapat bahwa strategi yang memanfaatkan bendabenda konkret, dan kemudian mengganti objek dengan model sederhana, seperti gambar, dapat mengembangkan keterampilan visualisasi siswa dalam belajar memecahkan masalah matematika. Strategi dan metode pengajaran yang sesuai dengan pendekatan CPA. Sebagaimana dinyatakan oleh Riccomini (2010), unsur-unsur penting dari belajar CPA terdiri dari tiga bagian: (1) belajar dengan memanipulasi benda konkrit, dengan menggunakan benda-benda konkrit yang sesuai; (2) belajar dari manipualsi gambar (berdasarkan benda konkrit sebelumnya), menggunakan gambar yang sesuai; dan (3) menggunakan pendekatan yang tepat untuk memfasilitasi siswa untuk tingkat pemahaman konsep abstrak, karena tidak mudah memahami perubahan dari gambar ke notasi abstrak (simbol/angka) tanpa arahan dari guru.

Berdasarkan pembelajaran di kelas, siswa yang mendapatkan pembelajaran CPA lebih atusias salam menerima pelajaran dibandingkan dengan siswa pada kelompok pembelajaran konvensional.Siswa yang mendapatkan pembelajaran CPA terlihat lebih leluasa dalam menggambar dibandingkan kelompok konvensional yang lebih terlihat kesulitan dalam menggambar berbagai bentuk bangun ruang. Akan tetapi, hal ini tidak terjadi langsung dalam pertemuan pertama. Pada pertemuan pertama, siswa di kelas eksperimen pun terlihat kesulitan dalam memvisualisasikan berbagai bentuk bangun ruang. Akan tetapi pada setiap pertmuan semakin terlihat perkembangan kemampuan spatial sense siswa. Temuan ini sejalan dengan pendapat Riccomini (2010) yang mencatat bahwa jika seorang siswa belum menguasai konsep/ keterampilan dalam salah satu tahap (konkrit, pictorial, atau abstrak) pada pendekatan CPA, guru harus mengulang belajar pada tahap terakhir yang belum dipahami siswa. kesulitan siswa pada awal-awal pertemuan juga dapat diakibatkan karena siswa belum terbiasa dengan pendekatan baru yang diterapkan dalam pembelajaran, hal ini sejalan dengan Brunner (dalam Yumiati, 2015) menunjukkan bahwa dalam melaksanakan pengajaran baru / metode pembelajaran di kelas, guru akan menghadapi kesulitan karena siswa perlu waktu untuk beradaptasi dengan situasi baru yang mereka hadapi.

Pencapaian KSS tertinggi dicapai oleh siswa dengan KAM tinggi; diikuti oleh siswa dengan KAM sedang dan KAM rendah. Hal ini tidak mengherankan karena dari hasil observasi dan dokumentasikegiatan belajar menggunakan CPA mengungkapkan bahwa siswa dengan KAM Tinggi lebih aktif dalam menyelesaikan tugas-tugas yang diberikan kepada mereka dalam lembar kerja kelompok. Mereka sering memimpin 
diskusi kelompok untuk menyelesaikan LKK. Dalam presentasi dan diskusi, para siswa KAM tinggi lebih aktif dalam memberikan pendapat mengenai solusi dari masalah matematika. Sejalan dengan situasi tersebut, Arends (dalam putri 2015) menyatakan, kemampuan siswa untuk belajar ide-ide baru tergantung pada pengetahuan awal mereka; untuk menguasai konsep matematika, siswa perlu menguasai konsep-konsep dasar matematika yang terkait dengan materi yang akan dipelajari.

Dari pembahasan ini, dapat disimpulkan bahwa pendekatan CPA dapat digunakan sebagai salah satu cara untuk mengembangkan Kemampuan Spatial Sense (KSS) siswa.

\section{E. KESIMPULAN}

Dengan demikian, dapat disimpulkan bahwa pencapaian KSS siswa yang mendapat pembelajaran dengan pendekatan CPA lebih baik secara signifikan dari siswa yang mendapat pembelajaran konvensional, jika dilihat secara keseluruhan dan kelompok KAM (tinggi, sedang, rendah). Pada kelompok KAM tinggi dan sedang, pencapaian KSS siswa untuk kelompok KAM tinggi yang mendapatkan pembelajaran dengan pendekatan CPA berada pada kriteria tinggi, sedangkan untuk kelompok KAM tinggi yang mendapatkan pembelajaran konvensional berada pada kriteria sedang. Pada kelompok KAM rendah, pencapaian KSS siswa untuk kelompok KAM rendah yang mendapatkan pembelajaran CPA berada pada kriteria sedang. Sedangkan, kelompok KAM rendah yang mendapatkan pembelajran konvensional berada pada kriteria rendah.

Pendekatan CPA dapat digunakan sebagai alternatif dari pendekatan pengajaran untuk mengembangkan Kemampuan Spatial Sense (KSS) siswa. Meskipun tidak ada satu pendekatan yang terbaik untuk digunakan dalam kelas heterogen, hasil penelitian ini menunjukkan bahwa pencapaian rasa spasial siswa yang menerima pelajaran dengan pendekatan CPA lebih baik secara signifikan daripada siswa yang belajar dalam pendekatan konvensional.

\section{DAFTAR PUSTAKA}

Arikunto, S. (2012). Dasar-dasar Evaluasi Pendidikan. Jakarta: PT. Bumi Aksara.

Gardner, H. (2003). Kecerdasan Majemuk : Teori dalam Praktek. Alih bahasa : Arvin Saputra. Batam : Interaksara

Harmony, J., \& Theis,R. (2012). Pengaruh Kemampuan Spasial Terhadap Hasil Belajar Matematika Siswa Kelas VII SMP Negeri 9 Kota Jambi. Jurnal Edumatica. Vol.2, No. 1.

Litbang Kemendikbud. 2015. Survei Internasional TIMSS http://litbang.kemendikbud.go.i d/index.php/surveiinternasional-timss/tentangtimss).

National Academy of Science (2006). Learning to Think Spatially. Washington DC: The National Academics Press

NCTM. (2000). Using the NCTM 2000 Principles and Standards with The Learning from Assessment materials. [Online]. Tersedia: http://www.wested.org/lfa/NCT M2000.PDF[25 Nopember 2016].

Riccomini, P. J. (2010). CRA Math Instruction: Systematically Connecting Concrete to Representation to Abstract. Prosiding Seminar pada MTSS 
Symposium. Kansas:
MTSS.

Saptini, R. D. (2016). Penerapan Pendekatan ConcretePictorial-Abstract untuk Meningkatkan Kemampuan Koneksi Matematis Siswa Sekolah Dasar. Skripsi UPI. Tidak diterbitkan.

Sugiyono. (2011). Metode penelitian Pendidikan pendekatan kuantitatif, kualitatif, dan $R \& D$. Bandung: Alfabeta.

Sugiyono. (2012). Metode Penelitian Pendidikan. Bandung: CV. Alfabeta

Suherman, E. dan Kusumah, Y.S. (1990). Petunjuk Praktis untuk Melaksanakan EvaluasiPendidikan

Matematika.

Wijayakusumah 157.

Suwaji, U.T. 2008. Permasalahan Pembelajaran Geometri Ruang SMP dan Alternatif Pemecahannya. Yogyakarta: Pusat Pengembangan dan Pemberdayaan Pendidik dan Tenaga Kependidikan Matematika.

Suwangsih, E. dan Tiurlina. (2009). Model Pembelajaran Matematika. Bandung: UPI Press.

Puspendik Kemendikbud. (2015). Hasil TIMSS 2015. [Online]. Tersedia:http://puspendik.kem endikbud.go.id/seminar/upoad/ Rahmawati-

Seminar\%20Hasil\%20TIMSS \%202015.pdf[27 Maret 2017]

Putri, H. E. (2017). Pendekatan Concrete-Pictorial-Abstract (CPA), Kemampuankemampuan Matematis dan Rancangan Pembelajarannya. Subang: Royyan Press.

H. E. (2015). Pengaruh Pendekatan ConcretePictorial-Abstract (CPA) terhadap Peningkatan

Kemampuan Representasi

Matematis, Spatial Sense, dan

Self-Efficacy Mahasiswa Calon

Guru Sekolah Dasar. Disertasi

Doktor pada SPS UPI

Bandung: Tidak diterbitkan.

Yuliawaty, L. (2011). Pembelajaran Matematika dengan

Pendekatan CRA (ConcreteRepresentational-Abstract)

untuk Meningkatkan

Kemampuan Pemahaman dan

Pemecahan Masalah

Matematik Siswa SMP.

(Tesis). Sekolah

Pascasarjana, Universitas

Pendidikan Indonesia,

Bandung.

Yumiati. (2015).Meningkatkan Kemampuan Berpikir Aljabar, Berpikir Kritis Matematis, dan Self-Regulated Learning Siswa Melalui Pembelajaran CORE.(Disertasi). Sekolah Pascasarjana, Universitas Pendidikan Indonesia, Bandung.

Witzel, B. S., Mercer, C. D., \& Miller, M. D. (2003). Teaching algebra to students with learning difficulties: An investigation of an explicit instruction model. Learning Disabilities: Research \& Practice, 18 (2), 121-131.

Witzel, W. S. (2005).Using CRA to Teach Algebra to Students with Math Difficulties in Inclusive Settings. $A$ Contemporary Journal 3(2), 49-60, $2005 . \quad$ [Online]. Tersedia:https://ehisebscohostcom.ezp.lib.unimelb.edu.au/ed s/pdfviewer/pdfviewer?vid=7\&s id=cd03d495-1 f99-4ec2-90d585ac8c67257b\%40sessionmgr 115\&hid $=116[20 \quad$ November 2016] 